\title{
Peritonealis dialízis, mint „bridge” terápia a szívtranszplantációig
}

\author{
Szegedi Andrea1, P. Szabó Réka², Pethő Ákos³, Kertész Attila', Maros Tamás', \\ Borbély Attila', Édes István', Csanádi Zoltán ${ }^{1}$
}

\author{
${ }^{1}$ Debreceni Egyetem, Klinikai Központ, Kardiológia és Szívsebészeti Klinika, Debrecen \\ ${ }^{2}$ Debreceni Egyetem, Klinikai Központ, Sebészeti Intézet, Debrecen \\ ${ }^{3}$ Semmelweis Egyetem, I. sz. Belgyógyászati Klinika, Budapest \\ Levelezési cím: \\ Dr. Szegedi Andrea, e-mail: andiszegedi@gmail.com
}

Egy iszkémiás cardiomyopathiában szenvedő 55 éves férfi betegnél súlyos koronáriabetegség miatt elvégzett koronária bypass-műtét és optimális gyógyszeres kezelés ellenére elörehaladott szívelégtelenség tüneteit, a balkamra-funkció progresszív romlását észleltük. Számos alkalommal hospitalizáltuk, mígnem diuretikum-refrakter ödémái miatt peritonealis dialízis $(\mathrm{PD})$ elindítása mellett döntöttünk. Rendszeres napi háromszori PD-kezelés után a vesefunkció javulása és a testsúly csökkenése mellett a bal kamrai szisztolés és diasztolés funkció javulását észleltük. A SwanGanz-mérések alapján a PD-kezelés elindítását követően a pulmonalis vaszkuláris rezisztencia jelentősen csökkent. A beteg a PD-kezelés elkezdését követően kórházi felvételt szívelégtelenség tünetei miatt nem igényelt, végül sikeres szivtranszplantáción esett át.

Kulcsszavak: szívelégtelenség, peritonealis dialízis, szívtranszplantáció

\section{Peritoneal dialysis as bridge therapy to heart transplantation}

A 53-year old male patient suffering from ischaemic cardiomyopathy underwent coronary bypass operation showed progressive signs of cardiac decompensation and deterioration of left ventricular (LV) ejection fraction despite optimal medical treatment. The patient was hospitalized several times because of recurrent peripheral oedema, which proved to be refractory to diuretic treatment. Therefore peritoneal dialysis (PD) was initiated. Through regular (three times daily) fluid exchange renal function improved, which was accompanied by a remarkable reduction in the body weight and a significant improvement of LV systolic and diastolic function. Moreover, subsequent Swan-Ganz catheterizations showed a significant decrease in the pulmonary vascular resistance. After the initiation of the PD, the patient did not require hospitalization for worsening heart failure and underwent successful heart transplantation.

Keywords: cardiac decompensation, peritoneal dialysis, heart transplantation

\section{Bevezetés}

A krónikus szívelégtelenség az egyik leggyakoribb kórházi felvételt igénylő kórkép, amelynek prevalenciája az idősebb korosztályban elérheti a $20 \%$-ot (1). A krónikus szívelégtelenségben szenvedők 36-50\%-ában krónikus veseelégtelenség alakul ki, amely egyrészt a nagy dózisban alkalmazott diuretikus terápiával, másrészt a perctérfogat csökkenésével hozható összefüg- gésbe (2). A peritonealis dialízis (PD) már több mint 60 éve biztonságosan alkalmazott módszer a veseelégtelen betegek tartós kezelésére (3). A közelmúltban közölt klinikai vizsgálatok alapján a PD indikációját nemcsak az akut és krónikus veseelégtelenség képezheti, hanem a súlyos pangásos szívelégtelenségben szenvedő betegek terápiájának is része lehet $(4,5,6)$. A PD-kezelés hatékonyságának alapját a pangásos szí- 
velégtelenség kialakulásáért felelős fokozott neurohormonális aktiváció képezi, amelynek során fokozódik a szimpatikus idegrendszer és a renin-angiotenzin-aldoszteron-rendszer (RAAS) aktivitása, nő az aldoszteron szekréciója, csökken a nátrium $\left(\mathrm{Na}^{+}\right)$filtrációja, nő a proximális $\mathrm{Na}^{+}$-reabszorpció. Következményesen a disztális tubulusokba kevesebb $\mathrm{Na}^{+}$jut és mivel a furosemid a disztális tubulusokban elsősorban a $\mathrm{Na}^{+}$-viszszaszívás gátlásán keresztül fejti ki hatását, így kevés $\mathrm{Na}^{+}$lévén a szer gyakorlatilag hatástalan marad $(7,8)$. A kombinált diuretikus terápia ellenére fokozódó és ismétlődő dekompenzáció - gondosan válogatott betegcsoportban - megszüntethető PD alkalmazásával. Klinikánkon több mint 3 éve alkalmazunk PD-kezelést súlyosan csökkent bal kamra szisztolés funkcióval bíró krónikus szívelégtelen betegeknél. A tartós PD alkalmazásának jótékony hatásairól számos irodalmi adat áll rendelkezésre krónikus pangásos szívelégtelenségben és jelenleg már arra is vannak adataink, hogy végstádiumú szívelégtelen betegek körében milyen szerepet tölthet be „bridge”-terápiaként a szívtranszplantációig.

\section{Esetbemutatás}

A PD-kezelés jótékony hatását igazolja 55 éves férfi betegünk kórtörténete, akinek 2013 szeptemberében keringésleállással, többszöri kamrafibrillációval szövődött anterior miokardiális infarktusa zajlott, amely kapcsán primer LAD-stentelés történt. $A$ bal fötörzset is érintő grávis háromér-betegség miatt néhány hónappal később myocardium revaszkularizációs (CABG) mütétre került sor 5 perifériás anasztomózis felhelyezésével. A sikeres CABG-mútét, optimális gyógyszeres kezelés, a pre- és posztoperatív időszakban is több alaklommal alkalmazott levosimendan kezelés ellenére a korábban is súlyos mértékben csökkent szisztolés balkamra-funkciója jelentősen nem javult. Többszöri kardiális dekompenzáció miatti hospitalizációt követően felmerült szívtranszplantáció lehetősége. Ismételt koronarográfia LIMA-LAD-okklúzió mellett jól vezető LAD-stentet és jól működő vénás graftokat mutatott, így intervencióra nem volt szükség. Állapotának romlását sem stent-, sem pedig graft-elégtelenség nem magyarázta, bal Tawaraszár-blokk hiányában jelentős javulás a reszinkronizációs kezeléstől sem volt várható. 2014. májusban végül a beteget szívtranszplantációs várólistára helyeztük.

Betegünk ezt követően több alkalommal került kórházi felvételre maximális kombinált vízhajtó terápia mellett fellépő dekompenzáció miatt, egy év alatt összesen 212 napot töltött kórházban. Végül alacsony perctérfogat-szindróma, súlyosbodó hipotónia miatt hosszas katekolamin kezelés vált szükségessé, ödémáit tartós intravénás diuretikus terápiával sem sikerült csökkenteni. Echokardiográfia a korábbi vizsgálatokkal összehasonlítva a stroke-volumen, a bal kamrai ejekciós frakció jelentős romlását mutatta (1. táblázat).
1. TÁBLÁZAT. Echokardiográfiával az egyes paraméterek változása 3 (I.), illetve 6 hónappal (II.) a CABG-mútétet követően

\begin{tabular}{|c|c|c|c|c|c|}
\hline & $\begin{array}{c}\text { LVEF } \\
\text { (\%) }\end{array}$ & $\begin{array}{c}\text { LVOTVTI } \\
\text { (m/s) }\end{array}$ & SV(ml) & $\begin{array}{c}\text { dp/dt } \\
\mathbf{( H g m m / s )}\end{array}$ & $\begin{array}{c}\text { TAPSE } \\
(\mathbf{m m})\end{array}$ \\
\hline I. & 28 & 0,08 & 37 & 790 & 8 \\
\hline II. & 24 & 0,065 & 22 & 556 & 8 \\
\hline
\end{tabular}

LVEF: left ventricular ejection fraction, LVOTVTI: left ventricular outflow tract velocity time integral, SV: Stroke volume, TAPSE: tricuspidal annular plane systolic excursion

Bal kamrai keringéstámogató eszköz (LVAD) behelyezésének lehetősége is felmerült, azonban nefrológussal konzultálva jelentős volumenterhelés, testszerte jelentkező ödémák és mérsékelten beszükült vesefunkció miatt vesepótló kezelés megkezdése mellett döntöttünk peritonealis dialízis (PD) formájában. 7 nappal a felvételét követően a PD-katéter perkután beültetése szövődménymentesen megtörtént, dialízise azonnal elkezdődött. Napi háromszori kezelés mellett néhány nap alatt állapota stabilizálódott, vérnyomása normalizálódott, vesefunkciója kis mértékben javult, testsúlya 12 kg-mal csökkent.

Betegünk állapotának javulását számos mérési adat tükrözi. Echokardiográfiával a peritonealis dialízis kezdetekor, illetve egy hónappal PD-kezelés elindítását követően pozitív irányba változó paramétereket találtunk (2. táblázat), a bal kamra szisztolés funkció javulását támasztotta alá a szöveti Doppler értékeinek változása is (1. ábra). A jobbkamra-funkció mérsékelt javulása mellett a bal kamra szisztolés funkciója mintegy 10\%kal nőtt, a számított pulzustérfogat csaknem megkét-

2. TÁBLÁZAT. Echokardiográfiával mért paraméterek változása peritoneális dialízis (PD) kezelés előtt és után

\begin{tabular}{|l|c|c|}
\hline & PD elött & PD után \\
\hline LA Diam (mm) & 54 & 51 \\
\hline EF (Teicholz \%) & 18 & 27 \\
\hline EF (Simpson \%) & 19 & 28 \\
\hline SV (Simpsonml) & 50 & 66 \\
\hline LVOT VTI (m/s) & 0,44 & 0,81 \\
\hline SV (ml) & 43 & 82 \\
\hline TAPSE (mm) & 7 & 8 \\
\hline MAPSE (mm) & 10,9 & 11,5 \\
\hline MV E vel (cm/s) & 87 & 73 \\
\hline MV DT (ms) & 92 & 79 \\
\hline Lat S (cm/s) & 4,6 & 6,3 \\
\hline Lat E' (cm/s) & 9,7 & 13,3 \\
\hline E/E' & 8,96 & 5,49 \\
\hline Tricuspidal S' (cm/s) & 16 & 20 \\
\hline Tricuspidal E' (cm/s) & 38 & 42 \\
\hline LA: Left atiun, EF: & & \\
\hline
\end{tabular}

LA: Left atrium, EF: ejection fraction, SV: stroke volume, LVOT VTI: Left ventricular outflow tract time velocity integral, TAPSE: Tricuspid annular plane systolic excursion, MAPSE: mitral annular plane systolic excursion, MV: Mitral valve 

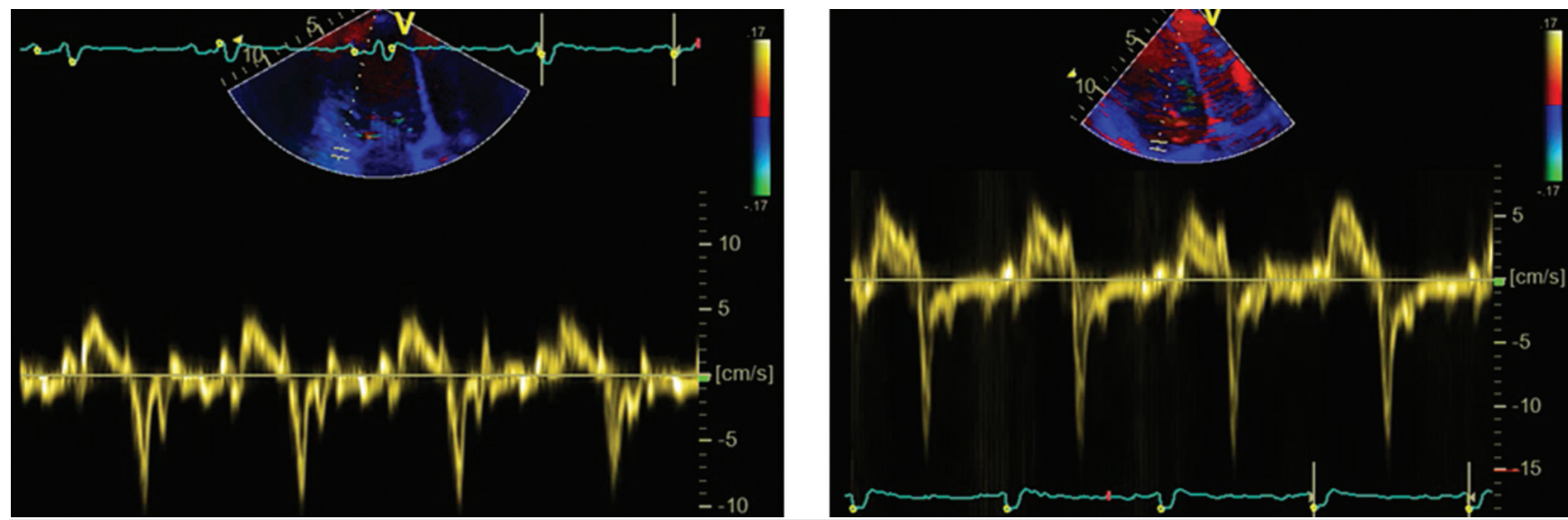

1. ÁBRA. Echokardiográfiával (szöveti Doppler) a mitralis billentyű laterális annulusánál mért sebességértékek változása peritonealis dialízis (PD) kezelés előtt (bal oldal) és után (jobb oldal)

szereződött, a diasztolés funkció javult, az enyhe fokú mitrális regurgitáció érdemben nem változott.

A szívtranszplantációs várólistán lévő betegek esetén félévente szükséges a Swan-Ganz-méréseket megismételni, így lehetőségünk volt a PD-kezelés előtti és utáni eredményeket összehasonlítani (3. táblázat). A Swan-Ganz-mérések alapján a PD-kezelést követően a stroke-volumen és perctérfogat jelentősen nem változott, ezen paraméterek és az echokardiográfiával mért hasonló adatok eltérésének magyarázatára lényeges okot nem találtunk. A beteg állapotának pozitív irányú változását mutatta az is, hogy az invazív mérés alapján a PD-kezelés után a pulmonalis vaszkuláris rezisztencia $43 \%$-kal csökkent, amely miatt már a reaktivitási teszt elvégzésére sem volt szükség.

A dialízis elkezdését követően a beteg kórházi felvételt szívelégtelenség rosszabbodása miatt nem igényelt, végül 2015. január közepén sikeres szívtranszplantáción esett át.

\section{Megbeszélés}

Hazánkban elsők között alkalmaztuk áthidaló terápiaként a PD-kezelést szívtranszplantáció előtt. Tapaszta-

3. TÁBLÁZAT. Jobb szívfél (Swan-Ganz) katéterezés során mért hemodinamikai paraméterek változása peritonealis dialízis (PD) kezelés előtt és után

\begin{tabular}{|l|c|c|}
\hline Swan-Ganz & $\begin{array}{c}\text { PD elkezdése } \\
\text { elött }\end{array}$ & PD után \\
\hline C.O. (I/min) & 3,02 & 2,58 \\
\hline SV (ml) & 47,2 & 43,7 \\
\hline PAPs (Hgmm) & 47 & 33 \\
\hline PAPm (Hgmm) & 33 & 28 \\
\hline PVR (DS/cm5) & 291 & 124 \\
\hline
\end{tabular}

C.O: cardiac output, SV: stroke volume, PAPs: pulmonary artery systolic pressure, PAPm: pulmonary artery mean pressure, PVR: Pulmonary vascular resistance lataink alátámasztják a nemzetközi irodalomban közölt eredményeket, amelyek szerint a PD-kezelés csökkenti a testsúlyt, javítja a diuretikumra adott választ, megőrzi a vesefunkciót, javítja a bal kamra szisztolés funkcióját és nem utolsósorban javítja a betegek életminőségét, valamint csökkenti a szívelégtelenség miatti hospitalizációk számát $(9,10)$. Végeredményben elmondhatjuk, hogy a PD - kardiológus és nefrológus szoros együttműködése alapján gondosan kiválasztott esetekben egy eredményes és költséghatékony terápiás módszer lehet a szívtranszplantációra váró végstádiumú szívelégtelenségben szenvedő betegek kezelésében.

\section{Irodalom}

1. Khalifeh N, Vychytil A, Hörl WH. The role of peritoneal dialysis in the management of treatmentresistant congestive heart failure: $\mathrm{A}$ European prospective. Kidney Int 2006; 70: S72-S75.

2. Arora N, Dellsperger KC. Heart failure and dialysis: new thoughts and trends. Adv Perit Dial 2007; 23: 72-76.

3. Schneierson SJ. Continuous peritoneal irrigation in the treatment of intractable edema of cardiac origin. Am J Med Sci 1949; 218: 76-9. 4. Sheppard R, Panyon J, Pohwani AL. Intermittent outpatient ultrafiltration for the treatment of severe refractory congestive heart failure. J Card Fail 2004; 10: 380-383.

5. Sara Querido, Patrícia Branco, Henrique Sousa, et al. Peritoneal dialysis as a successful treatment in patients with refractory congestive heart failure: a one-center experience. Clinical Nephrology 2016; 85(5) 260-265.

6. Kunin M, Arad M, Dinour D, et al. Peritoneal Dialysis in Patients with Refractory Congestive Heart Failure: Potential Prognostic Factors. Blood Purif 2013; 35: 285-294.

7. Ellison DH. The physiologic basis of diuretic synergism: its role in treating diuretic resistance. Ann Intern Med 1991; 114: 886-894. 8. Broekman KE, Sinkeler SJ, Waanders F, et al. Volume control in treatment-resistant congestive heart failure: role for peritoneal dialysis. Heart Fail Rev 2014 Nov; 19(6): 709-16. PubMed

9. Karlien François, Joanne M Bargman. Evaluating the benefits of home-based peritoneal dialysis. International Journal of Nephrology and Renovascular Disease 2014; 7: 447-455.

10. Lu RA, Muciño-Bermejo MJ, Ribeiro LC, et al. Peritoneal Dialysis in Patients with Refractory Congestive Heart Failure: A Systematic Review. Cardiorenal Med 2015; 5: 145-156. 